\title{
Self-Organization of Porphyrin-Peptide Units by Metal-Mediated Peptide Assembly\#
}

\author{
Idalina M. M. Carvalho ${ }^{a}$ and Michael Y. Ogawa*,b \\ ${ }^{a}$ Departamento de Química Orgânica e Inorgânica, Universidade Federal do Ceará, \\ CP 12200, 60455-960 Fortaleza - CE, Brazil \\ ${ }^{b}$ Department of Chemistry and Center for Photochemical Sciences, Bowling Green State University, \\ Bowling Green, $\mathrm{OH} 43403$, USA
}

\begin{abstract}
O polipeptídeo H21(30-mer) forma dímeros "coiled-coil” que apresentam dois resíduos histidínicos expostos ao solvente nos lados opostos de sua superfície. Este peptídeo reage com a protoporfirina IX de cobalto, Co(ppIX), para produzir [Co(ppIX)\{(H21(30-mer) $\left.\}_{2}\right]$, como determinado por espectroscopia UV-Vis. Esta ligação bi-axial disponibiliza um potencial domínio de oligomerização "coiled-coil" em cada face do anel porfirínico de cobalto. Dicroísmo circular e cromatografia líquida de exclusão de alto desempenho forneceram evidências da auto-organização destas unidades porfirina-peptídeo em solução. A evaporação da solução porfirina-peptídeo em uma superfície sólida resultou na formação de longos materiais cilíndricos com milímetros de comprimento e micrometros de diâmetro. A presença do complexo $\mathrm{Co}(\mathrm{ppIX})$ nestes materiais foi confirmada por microscopia Raman. Estes materiais, entretanto, foram formados somente com o tampão fosfato, e não com tampões orgânicos ou água pura, indicando que sua formação deve envolver um processo mais complicado do que originalmente antecipado.
\end{abstract}

The polypeptide H21(30-mer) folds into a two-stranded coiled-coil in which two solventexposed histidine residues reside on opposite sides of its surface. This peptide was allowed to react with cobalt(III) protoporphyrin IX, $\mathrm{Co}(\mathrm{ppIX})$, to produce $\left[\mathrm{Co}(\mathrm{ppIX})\left\{(\mathrm{H} 21(30-\mathrm{mer})\}_{2}\right]\right.$, as determined by UV-Vis spectroscopy. This bis-axial ligation thus positions a potential coiledcoil oligomerization domain onto each face of the cobalt porphyrin ring. Circular dichroism spectroscopy and high performance size exclusion chromatography provide evidence for the solution-phase self-assembly of these porphyrin-peptide units. Evaporation of the porphyrinpeptide solution on a solid support results in the formation of long rod-like materials having millimeter-scale lengths and micron-scale diameters. The presence of $\mathrm{Co}(\mathrm{ppIX})$ in these materials was confirmed by Raman microscopy. However, they were formed only from phosphate buffer, and not from organic buffers or pure water, indicating that their formation might involve a more complicated process than originally anticipated.

Keywords: cobalt protoporphyrin IX, peptides, fibers, self-assembly

\section{Introduction}

Molecular self-assembly has proven to be a valuable approach towards the bottom-up design of synthetic materials. ${ }^{1-5}$ Much inspiration for this work comes from biological precedents in which optimal combinations of hydrogen-bond, electrostatic, and hydrophobic interactions are used to assemble polypeptides and nucleic acids into robust structural motifs. ${ }^{2,4}$ To further expand the tools for

*e-mail: mogawa@bgsu.edu

\#Dedicated to the memory of Professor Icaro de Sousa Moreira, a great friend and wonderful colleague. His professional talents and personal qualities made lasting contributions to our lives. preparing such materials, continuing efforts are being directed towards gaining a better understanding of how various combination of non-covalent interactions can be used to prepare self-assembled materials having predictable and well-defined morphologies. ${ }^{6,7}$

Inspired by workers in the field of supramolecular coordination chemistry, we $\mathrm{e}^{8-12}$ and others ${ }^{13-16}$ have been exploring a new route for preparing self-assembled materials which uses transition metal chemistry to help direct the organization of self-assembling polypeptides in ways that may add to, and perhaps complement, the existing repertoire of native protein structures. This approach of "metal-mediated peptide assembly" coordinates 
self-assembling polypeptide chains to transition metal complexes in order to create metal-peptide tecton units which can then be joined together through inter-unit peptide-peptide interactions.

Our work has thus focused on the use of polypeptides that are able to form the non-covalent structure of $\alpha$-helical coiled-coils in order to provide oligomerization domains for these metal-peptide tectons. ${ }^{8,9}$ Coiled-coils are a common protein structure motif which exists as a left-handed supercoiling of two or more $\alpha$-helices that is stabilized by specific hydrophobic interactions between the different helical chains of this non-covalent peptide assembly. ${ }^{17}$ To this end, a polypeptide designed to form a $\alpha$-helical coiledcoil was derivatized with a metal-binding 4-pyridylalanine site at its surface and then coordinated to the cis positions of a Pt(ethylenediamine) metal center in order to produce a tecton unit in which two coiled-coil forming peptides are oriented at right angles from each other. It was found that these units could then be linked together by inter-unit coiled-coil formation to simultaneously produce both globular and fibrillar assemblies having dimensions on the order of $10-100 \mathrm{~nm}^{8}$

In this paper, the design of a different type of metalpeptide tecton will be described involving the coordination of a different coiled-coil forming polypeptide, called $\mathrm{H} 21$ (30-mer), ${ }^{18}$ to the axial positions of cobalt(III) protoporphyrin IX, Co(ppIX). The H21(30-mer) was previously shown to favor the formation of two-stranded coiled-coils and this coordination places the two coiled-coil oligomerization domains on opposite faces of the cobalt porphyrin ring. Results will be presented to show that these tectons can indeed self-assemble by inter-unit coiled-coil formation in solution and give rise to rod-like structures having millimeter-scale lengths and micron-scale diameters upon evaporation onto a solid support.

\section{Experimental}

\section{Materials}

The Fmoc-protected $L$-amino acid derivatives where Fmoc $=$ fluorenylmethyloxycarbonyl, $2-(1 \mathrm{H}$-benzotriazole 1-yl)-1,1,3,3-tetramethyluronium hexafluorophosphate (Hbtu), and anhydrous hydroxybenzotriazole (HObt) were purchased from Peptides International Inc. (Louisville, $\mathrm{KY}$ ). $N$-methylpyrrolidone (nmp) was purchased from Applied Biosystems Inc. (Carlsbad, CA). Piperidine, $\mathrm{N}, \mathrm{N}$-diisopropylethylamine, and protoporphyrin IX cobalt(III) chloride were purchased from Sigma-Aldrich (St. Louis, MO). All reagents were used as received without further purification.

\section{General methods}

UV-Vis absorption spectra were recorded on a HewlettPackard model 8452A diode array spectrophotometer. Circular dichroism spectra were obtained on an Aviv model 202-01DS circular dichroism spectrometer (Lakewood, NJ) using a rectangular $0.1 \mathrm{~cm}$ or $0.5 \mathrm{~cm}$ pathlength cell. The spectra were obtained as an average of 3-5 scans using $1 \mathrm{~nm}$ steps. Scanning electron-microscopy was performed on an Inspect F scanning electron microscope (FEI Co.; Hillsboro, OR). Samples were prepared by evaporating peptide/porphyrin solutions on conductive carbon tape and examined without coating. Raman microscopy was performed on a Renishaw inVia Raman confocal microscope using $442 \mathrm{~nm}$ excitation.

\section{Peptide synthesis}

The peptide H21(30-mer) was prepared and purified as previously described ${ }^{18}$ on an Applied Biosystems Model 433 A peptide synthesizer by standard Fmoc-chemistry with the manufacturer's amide resin.

\section{Assembly formation}

The metal-peptide assemblies were formed by mixing either $1 \mathrm{mmol} \mathrm{L}^{-1} \mathrm{H} 21$ (30-mer) and $0.5 \mathrm{mmol} \mathrm{L}^{-1} \mathrm{Co}$ (ppIX), or $600 \mu \mathrm{mol} \mathrm{L}^{-1} \mathrm{H} 21\left(30\right.$-mer) and $300 \mu \mathrm{mol} \mathrm{L}{ }^{-1} \mathrm{Co}$ (ppIX) in $5: 95 \%(\mathrm{v} / \mathrm{v}) \mathrm{dmf} /$ phosphate buffer $\left(20 \mathrm{mmol} \mathrm{L}^{-1} \mathrm{KH}_{2} \mathrm{PO}_{4} /\right.$ $\mathrm{K}_{2} \mathrm{HPO}_{4}, \mathrm{pH} 7.0$ ) and incubating at $60^{\circ} \mathrm{C}$ for 2-24 h. Before analysis, the crude reaction mixture was extracted with dichloromethane to remove any unreacted $\mathrm{Co}(\mathrm{ppIX})$ from the aqueous reaction mixture.

\section{High performance size exclusion chromatography (HPSEC)}

HPSEC experiments were performed on a Superdex 75 10/300 GL column (GE Healthcare BioSciences Corp., Piscataway, NJ) having a molecular weight range of 3-70 kD for globular proteins. The column was connected to a Waters Model 515 high performance liquid chromatography system equipped with Waters Model 996 diode array detector. Samples of the assembly formation solution were eluted using a $50 \mathrm{mmol} \mathrm{L}^{-1}$ $\mathrm{KH}_{2} \mathrm{PO}_{4} / 100 \mathrm{mmol} \mathrm{L}^{-1} \mathrm{KCl}$ buffer, $\mathrm{pH}$ 7.0, with a flow rate of 0.3-0.4 $\mathrm{mL} \mathrm{min}^{-1}$ and monitored at a wavelength of $230 \mathrm{~nm}$.

\section{Results and Discussion}

The H21(30-mer) peptide used in this work had the sequence Ac-K(IEALEGK) ${ }_{2}$ (IEALEHK)(IEALEGK)G-NH, 
whose metallated derivative was shown to assemble into a two-stranded $\alpha$-helical coiled-coil. ${ }^{18}$ Importantly, the sequence of $\mathrm{H} 21$ (30-mer) places a metal-coordinating histidine residue at position 21 which would become fully solvent-exposed upon formation of a coiled-coil. This design thus places metal-binding sites on opposite surfaces of the coiled-coil structure, and it was anticipated that subsequent coordination of the coiled-coil to the axial positions of the metalloporphyrin would produce the desired metal-peptide tecton unit.

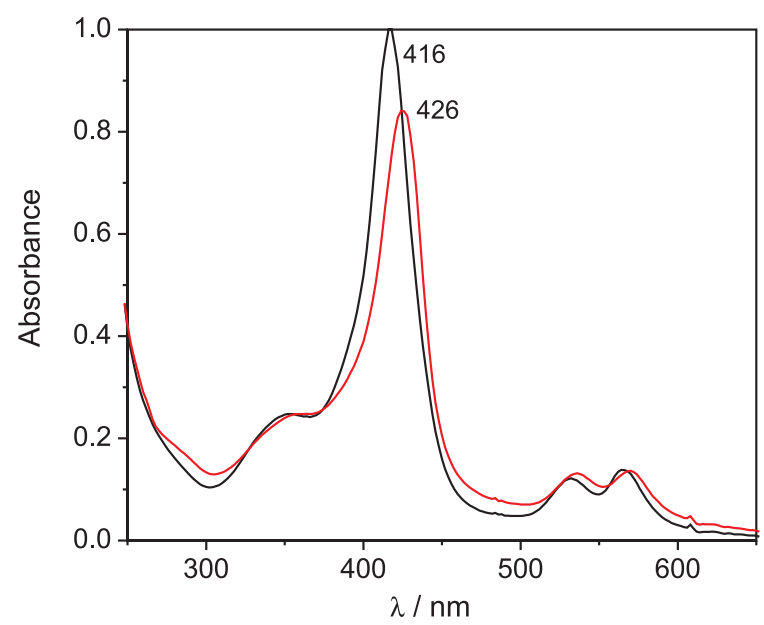

Figure 1. UV-Vis spectra of $\operatorname{Co}(\mathrm{ppIX})$ chloride $\left(15 \mu \mathrm{mol} \mathrm{L} \mathrm{L}^{-1}\right.$ in $5 \% \mathrm{v} / \mathrm{v}$ $\mathrm{dmf} / 20 \mathrm{mmol} \mathrm{L}^{-1}$ phosphate buffer, $\mathrm{pH} 7$ ) taken before (black) and after (red/grey) the addition of 5-fold molar excess of H21(30-mer) dissolved in $20 \mathrm{mmol} \mathrm{L}^{-1}$ phosphate buffer, $\mathrm{pH} 7$.

Solutions of H21(30-mer) and Co(ppIX) were mixed together and incubated at $60{ }^{\circ} \mathrm{C}$ overnight under ambient conditions. Figure 1 shows that this reaction resulted in a loss of intensity of the porphyrin Soret band accompanied by a red-shift from 416 to $426 \mathrm{~nm}$. The porphyrin absorption bands at 534 and $564 \mathrm{~nm}$ also red-shift upon the addition of the peptide. These spectral changes are identical to those previously reported for the formation of $\left[\mathrm{Co}(\mathrm{ppIX})(\mathrm{py})_{2}\right]$ in alcoholic solvents ${ }^{19}$ and suggests that the reaction of H21(30-mer) with $\mathrm{Co}(\mathrm{ppIX})$ results in the formation of a six-coordinate cobalt(III) porphyrin species in which two separate peptides are bound to the axial positions of Co(ppIX).

Initial evidence for the self-assembly of the H21 (30-mer) / Co(ppIX) tectons was obtained from the circular dichroism (CD) spectrum of the reaction mixture (Figure 2) which displayed strong negative peaks at 208 and $222 \mathrm{~nm}$ with an ellipticity ratio of $\theta_{222} / \theta_{208} \cong 1.06$, and thus shows the existence of $\alpha$-helical coiled-coils in the solution..$^{20}$ The spectrum also shows a small induced $\mathrm{CD}$ band in the Soret region of the spectrum consisting of a negative peak at $420 \mathrm{~nm}$ and maximum at $434 \mathrm{~nm}$.
The presence of this band suggests that the porphyrin ring exists within the chiral peptide environment. ${ }^{21}$ Further evidence for the assembly of the metal-peptide tectons can be seen in Figure 3 which compares the HPSEC elution profiles of the peptide and porphyrin starting materials to that of the reaction mixture. The peptide and porphyrin alone are seen to elute from the column with retention times of ca. 43 and $53 \mathrm{~min}$, respectively. However, after overnight incubation at $60{ }^{\circ} \mathrm{C}$, the relative intensities of these peaks have diminished and a broad peak appeared just before the apopeptide to indicate a distribution of higher molecular weight species. In addition, a new peak is also seen to elute at $19 \mathrm{~min}$, which corresponds to the column void volume and a molecular mass of $>70 \mathrm{kDa}$. Each of these new species display Soret absorption bands indicating the presence of Co(ppIX).

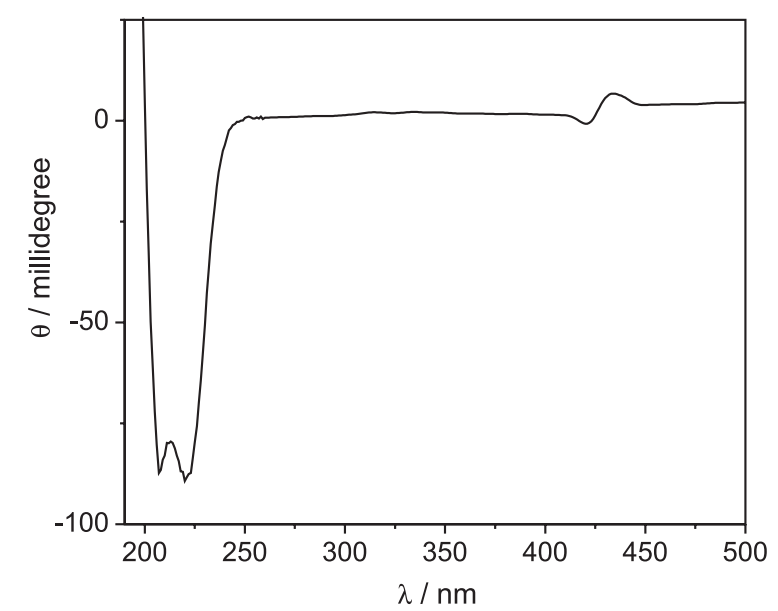

Figure 2. Circular dichroism spectrum of a solution consisting of $150 \mu \mathrm{mol} \mathrm{L}-1 \mathrm{Co}(\mathrm{ppIX})(0.1 \% \mathrm{NaOH})$ and $300 \mu \mathrm{mol} \mathrm{L} \mathrm{L}^{-1} \mathrm{H} 21-30 \mathrm{mer}$ in $20 \mathrm{mmol} \mathrm{L}^{-1}$ phosphate buffer, pH 7.
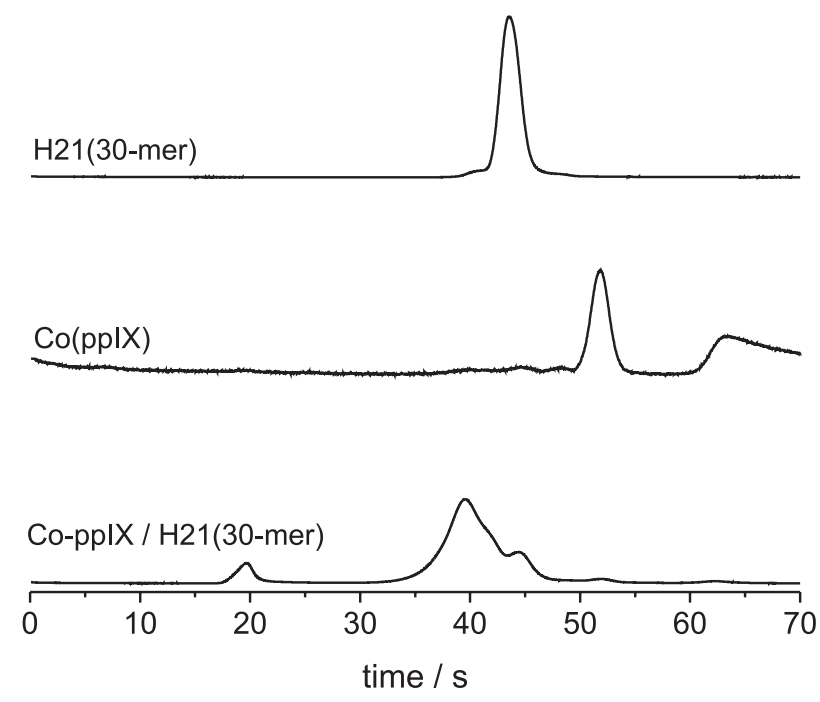

Figure 3. HPSEC profiles of H21(30-mer) (top), Co(ppIX) (middle) and reaction mixture after overnight incubation at $60^{\circ} \mathrm{C}$ (bottom). 

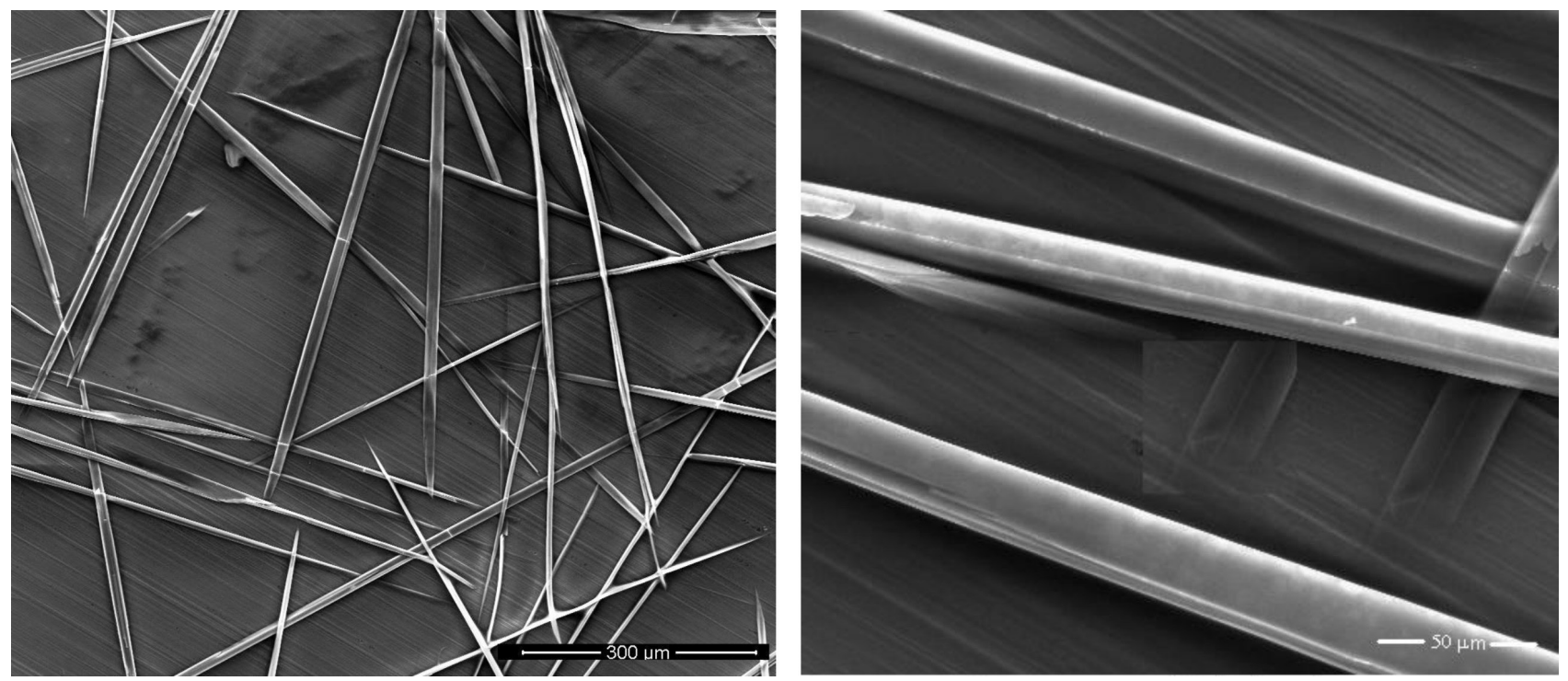

Figure 4. SEM images of structures formed after incubation of $\mathrm{Co}(\mathrm{ppIX})$ / H21(30-mer) complexes and evaporation at room temperature on copper tape.

To examine whether these new peptide-porphyrin assemblies can form structured materials in the solid state, samples of the incubated tecton mixture were deposited onto conductive copper tape and allowed to dry under ambient conditions for scanning electron microscopy studies. Figure 4 shows that this treatment results in the presence of extremely large rod-like structures having millimeter-scale lengths and micronscale diameters. It is noted that, under identical conditions, such materials cannot be formed from samples of either the peptide or porphyrin alone, nor from peptide-porphyrin mixtures dissolved in either organic buffers (HEPES, (4-(2-hydroxyethyl)-1-piperazineethanesulfonic acid, and TRIS, tris(hydroxymethyl)aminomethane) or pure water.

The composition of the rod-like materials was analyzed by Raman microscopy (Figure 5), which shows signals identical to those seen from samples of the $\mathrm{Co}^{\mathrm{III}}(\mathrm{ppIX})$ alone and which compares favorably to those previously assigned to the in-plane vibrational modes of the $\mathrm{Co}^{\mathrm{III}}(\mathrm{ppIX})$ ring taken in piperidine. ${ }^{22}$ However, signals associated with the amide I and amide II bands of the coiled-coil $\alpha$-helix were not observed, as these are presumably masked by the resonance enhanced porphyrin signals since excitation at $442 \mathrm{~nm}$ was used in these experiments.

It is noted that the morphology of the Co-peptide materials is strikingly different from those previously prepared from the reaction of the related peptide AQPal14 with $c i s$ - $\mathrm{Pt}($ ethylenediamine $)\left(\mathrm{NO}_{3}\right)_{2}{ }^{8}$ Those earlier assemblies had lengths on the order of several hundred nanometers, thicknesses ranging from 4-10 nm, and appeared to be more flexible than the $\mathrm{Co}(\mathrm{ppIX}) /$ peptide materials shown in Figure 4. The original design of such materials predicted that these differences might arise

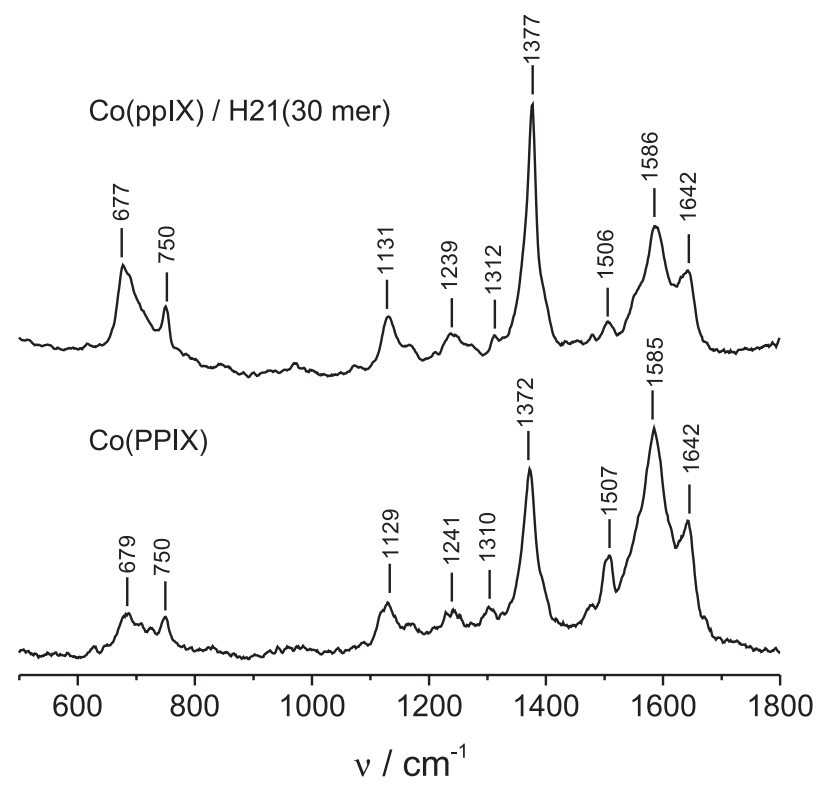

Figure 5. Raman $\left(\lambda_{\text {ex }}=442 \mathrm{~nm}\right.$ ) spectra obtained from (top) structures produced from the incubation of $\mathrm{Co}(\mathrm{ppIX}) / \mathrm{H} 21$ (30-mer) and (bottom) Co(ppIX) alone.

from the stereochemical properties of the various metal complexes used to direct the assembly of the peptide structures. Thus, the coordination of two peptides to the cis-positions of the Pt center likely imparts a degree of conformational variation to their supramolecular assemblies which might limit their ability to efficiently pack against one another to produce the observed mixture of globular structures and narrow, flexible fibers. In contrast, the coordination of peptides to the trans axial positions of $\mathrm{Co}(\mathrm{ppIX})$ was expected to enforce a more linear geometry in the growing assemblies and yield materials having a more unidimensional morphology. Whereas such structures are 
indeed observed in Figure 4, it is noted that they could only be formed from phosphate buffer, but not HEPES, TRIS or pure water. Since it is known that all of these solvents are amenable to the formation of $\alpha$-helical coiled-coils, these results indicate that the rod-like materials might arise from a more complicated mechanism than originally anticipated. Ongoing studies are being conducted to better understand the nature of these rod-like peptide-porphyrin materials.

\section{Acknowledgments}

This work was supported by NSF grant No. CHE0455441 and ACS-PRF grant No. 34901-AC. I. M. M. C. thanks CAPES for grant No. 4174/08-9. The authors thank Professor Phil Castellano for use of the Raman microscope and Professor H. Peter Lu for access to the scanning electron-microscope in the Center for Photochemical Sciences at Bowling Green State University, USA.

\section{References}

1. Fujita, M.; Tominaga, M.; Hori, A.; Therrien, B.; Acc. Chem. Res. 2005, 38, 369.

2. Zhang, S. G.; Nat. Biotechnol. 2003, 21, 1171.

3. Leininger, S.; Olenyuk, B.; Stang, P. J.; Chem. Rev. 2000, 100, 853.

4. Lindsey, J. S.; New J. Chem. 1991, 15, 153.

5. Lehn, J. M.; Angew. Chem., Int. Ed. 1990, 29, 1304.

6. Armstrong, C. T.; Boyle, A. L.; Bromley, E. H. C.; Mahmoud, Z. N.; Smith, L.; Thomson, A. R.; Woolfson, D. N.; Faraday Discuss. 2009, 143, 305.

7. Pepe-Mooney, B. J.; Fairman, R.; Curr. Opin. Struct. Biol. 2009, $19,483$.
8. Tsurkan, M. V.; Ogawa, M. Y.; Biomacromolecules 2007, 8, 3908.

9. Tsurkan, M. V.; Ogawa, M. Y.; Chem. Commun. 2004, 2092.

10. Ogawa, M. Y.; Fan, J.; Fedorova, A.; Hong, J.; Kharenko, O. A.; Kornilova, A. Y.; Lasey, R. C.; Xie, F.; J. Braz. Chem. Soc. 2006, 17, 1516.

11. Kharenko, O. A.; Kennedy, D. C.; Demeler, B.; Maroney, M. J.; Ogawa, M. Y.; J. Am. Chem. Soc. 2005, 127, 7678.

12. Kharenko, O. A.; Ogawa, M. Y.; J. Inorg. Biochem. 2004, 98 , 1971.

13. Przybyla, D. E.; Chmielewski, J.; J. Am. Chem. Soc. 2008, 130, 12610.

14. Dublin, S. N.; Conticello, V. P.; J. Am. Chem. Soc. 2008, 130, 49.

15. Salgado, E. N.; Lewis, R. A.; Faraone-Mennella, J.; Tezcan, F. A.; J. Am. Chem. Soc. 2008, 130, 6082.

16. Ghosh, S.; Verma, S.; Tetrahedron Lett. 2007, 48, 2189.

17. Gunasekar, S. K.; Haghpanah, J. S.; Montclare, J. K.; Polym. Adv. Technol. 2008, 19, 454.

18. Kornilova, A. Y.; Wishart, J. F.; Xiao, W. Z.; Lasey, R. C.; Fedorova, A.; Shin, Y. K.; Ogawa, M. Y.; J. Am. Chem. Soc. 2000, 122, 7999.

19. Dokuzovic, Z.; Ahmeti, X.; Pavlovic, D.; Murati, I.; Asperger, S.; Inorg. Chem. 1982, 21, 1576.

20. Kohn, W. D.; Mant, C. T.; Hodges, R. S.; J. Biol. Chem. 1997, $272,2583$.

21. Hagarman, A.; Duitch, L.; Schweitzer-Stenner, R.; Biochemistry 2008, 47, 9667.

22. Woodruff, W. H.; Adams, D. H.; Spiro, T. G.; Yonetani, T.; J. Am. Chem. Soc. 1975, 97, 1695.

Received: November 16, 2009 Web Release Date: April 15, 2010 